ISBN 978-93-86878-09-0

10th International Conference on Language, Humanities, Education and Social Sciences

(ICLHESS-18)

Bali (Indonesia) Jan. 12-13, 2018

\title{
Does Organizational Climate Affects on Employee Happiness Among Lecturer in Indonesia?
}

\author{
Megawati Batubara ${ }^{1}$, Azhar El Hami ${ }^{2}$ \\ ${ }^{1}$ Faculty of Psychology, Universitas Padjadjaran, Indonesia \\ ${ }^{2}$ Faculty of Psychology, Universitas Padjadjaran, Indonesia
}

\begin{abstract}
Achieving employee happiness is not easy. In the current era of global competition, organizations are faced with a complex and dynamic work environment. Increased business targets, use new technology, restructuring organization and differences employee status. This working environment condition puts enough pressure on employees and it becomes important for organization to create a good working environment. A healthy work environment to support the physical and psychological health of workers, and help workers master jobs, and face things like stress and pressure (Kelloway \& Day, 2005). Not realizing a good working environment will have an impact on employee unhappiness. Pressures emerging from environmental aspects such as job-related stress, low levels of occupational safety and health, stress, and other inadequate facilities lead to lower employee happiness (Kiriago \& Bwisa, 2013). This study aims to find out the contribution of work environment to happiness at work among lecturer in Indonesia. Work environment as a organizational and happiness at work measured by questionnaires with valid item and 0.90 point of alpha cronbach in. The data analyzed using SPSS ver 2.0 with regression test. The results of data retrieval conducted on 107 lecturers in state university, found that work situation has a high enough role to the happiness at work, with contribution value of $61,1 \%$ and coefficient level of 0,782. This means that the high level of employee happiness is strongly influenced by the work situation. When the work situation is felt less conducive, it is quite predictable that the happiness of employees in the workplace becomes disrupted.
\end{abstract}

Keywords: work environment, organizational climate, happiness at work, lecturer, indonesia

\section{Introduction}

Work as an employee identically with work in organization. Organization needs the productivity from their employees and employees have an effort to realize the vision and mission of the organization. There are several previous studies have shown that organizations expect a high level of performance and productivity from their employees (Thompson \& Goodale, 2006 and Samnani \& Singh, 2014). Most companies need productive workforce to qualify, so they can contribute to the organization's goals (Chong \& Eggleton, 2007 and Hales \& Williamson, 2010). Based on the results, it is clear that the organizations wants high productivity from their employees. The other side, organizations does various ways to make their employees productive. One of them by building happiness in the workplace, because organization is one of the factor which is able to build and maintain employee happiness at workplace.

In general, happiness may be defined as the experience of frequent positive affect, infrequent negative affect and an overall sense of satisfaction with life as a whole (Myers \& Diener, 1995). Being happy is of great importance to most people, and happiness has been found to be a highly valued goal in most societies (Diener 2000). But in specific way at the workplace, happiness refers to how productive employees are with their work. There are several research that discuss about employee happiness at work and specific related to employee productivity. In Quick \& Quick (2004) and Rego \& Cunha (2008) states that happy employees are productive employees. Conversely, unhappiness in the workplace will reduce productivity (Fereidouni, Najdi \& Amiri, 
2013). Other studies suggest that by keeping happiness in the workplace, it can improve employee productivity (Quick \& Quick, 2004). With the results of this studies, it can be said that the happiness of employees in working closely with the productivity of work.

The pursuit of employee happiness is not easy. In the current era of global competition, organizations are faced with a complex and dynamic work environment. The work environment is so rapidly changing. Increased business use of new technology, restructuring organization and differences in employee status. This working environment condition puts enough pressure on employees. This condition becomes important for organization to create a good working environment. A healthy work environment to support the physical and psychological health of workers, and help workers master jobs, and face things like stress and pressure (Kelloway \& Day, 2005). Organization that can not realizing a good working environment will have an impact on employee unhappiness. Pressures emerging from environmental aspects such as job-related stress, low levels of occupational safety and health, stress, and other inadequate facilities lead to lower employee happiness (Kiriago \& Bwisa, 2013). Working enviroment identified as a organizational climate.

Above the explanation, it can be concluded that is very important for the organization to build a good working environment or organizational climate. Organizational climate can increase employees happiness in the work place. A happy employee will deliver productive performance and contribute to achieve organization's vision and mission. Therefore, the purpose of this study is to measure the role of organizational climate in building or affects on employees happiness. Basically, the measurement in this research can be done throughout all organizations. In this studi, conducted in the educational organization, university. The consideration is that the university is undergoing organizational restructuring, unclear new policies, changes the employee status, increased job targets, enactment of new online system, new version of performance appraisal, changes of reward punishment system and conflict can not solved constructively. It can be concluded that the university has unfavorable organizational climate. The member of university that the most exposed to this condition is the lecturer. So, if it refers to some research results, it can be ascertained that this condition makes the lecturer unhappy. These conditions are increasingly strengthening to measure the role of organizational climate in building or affects on employees happiness, especially in lecturer in Indonesia.

\section{Literatur Review}

Happiness is umbrella concept that includes a large number of constructs. In the past two decades, a number of new constructs have emerged which reflect some form of happiness or positive affective experiences in the work place. What these constructs have in common is that all refer to pleasent jugdement (positive attitudes) or pleasant experiences (positive feelings, moods, emotions, flow states) at work. In the work place, happiness is influenced by both short-lived events and chronic conditions in the task, job and organization (Fisher, 2010). It is also influenced by stable attributes of individual's expectations, needs, and preferences. There are three aspects to build the happy feelings : (1) Work itself; (2) The job including contextual features; and (3) The organization as a whole (Fisher, 2010).

Organizational climate has many definitions. In this research, the theory used is from Litwin and Stringer (1968). The organizational climate is a concept describbing the subjective nature or quality of the organizational environment. The climate of an organization could be defined operationally as the sum of the perceptions of individual working in that organization. The term organizational climate refers to a set of measurable properties of the work environment, perceived directly or indirectly by the people who live and work in this environment and assumed to influence their motivation and behavior. Litwin \& Stinger (1968) developed nine dimension that constituted organizational climate, include (1) Structure; (2) Responsibility; (3) Reward; (4) Risk; (5) Warmth, (6) Support; (7) Standars; (8) Conflict; and (9) Identity. 


\section{Methods}

This research method is applied using a nonexperimental approach. Participant researchers used a nonprobability technique sampling. The population of this research is lecturers in university. To determine a selected sample, lecturers were selected for a minimum term of six months, on the assumption that they had been exposed the environment of university for long enough. 107 lecturers that fitted these criteria were selected.

The verification method is done to test the hypothesis by using statistical tests. In this research, data collection is conducted by using two questionnaire. Analysis of validity item quentionnaire used Spearman rank. The results is all items having a value above 0.3, indicates that the item is valid. Organizational climate questionnaire with 36 valid items and happiness at work questionnaire with 27 valid items. Analysis of reliability measured by Alpha Cronbach shows the level of high reliability, with the result of these two questionnaire is 0.90 point. The questionnaire includes demographic data (gender, age, tenure, employee status and marital status). The data analyzed using SPSS ver 2.0 with regression test.

\section{Result and Discuss}

Organizational climate is a lecturer's appreciation of the work situation at the university, which is felt through nine aspects, namely (1) Structure, which consists of organizational goals, level of responsibility and organizational values. The structure is the level of coercion that employees feel because of the rules and procedures are arranged. It is important for employees to know that what is really expected of them and they can make the right contribution to the organization. The higher the "structuring" of an organization the environment will feel more rigid, closed, and full of threats. While more autonomy and freedom of self-determination are given to the individual and the more attention management gives to employees, the better the work climate. (2) Responsibility, is the level of supervision imposed by the organization and felt by the employees. Where quality and form of supervision, direction and guidance received from superiors to subordinates.

Next aspects are (3) Reward, is the level of reward given to the employee's business. Employees are rewarded according to their performance. Leaders who give more recognition than criticism to help employees reach the top of achievement. (4) Risk, give the employee space to perform or take risks in performing the task as a challenge. (5) Warmth, relating to the level of employee satisfaction associated with organizational integrity. Feelings of a friendly working atmosphere and more emphasis on hospitality or friendship conditions in an informal group, as well as good relationships among colleagues, an emphasis on the influence of friendship and informal social groups. (6) Support, related to support to employees in performing the duties of the organization. Matters related to support and relationships among colleagues is a feeling of mutual help between leaders and employees, more emphasis on mutual support between superiors and subordinates.

The last three aspects are (7) Standard, an employee's perception of the interests of the goals and performance standards, both implicit and explicit, emphasized on better execution of work and the challenge of achieving individual and group goals. Employees must do a good job to improve their performance in order to achieve the targets that have been determined. (8) Conflict, conflicts are created due to differences of opinion between leaders and subordinates. The difference will be positive if the leader will listen to the opinions of subordinates and both parties are willing to put the problem openly and seek solutions together. (9) Organizational Identity and Loyalty, relates to a feeling of pride in the organization's existence and loyalty demonstrated during its lifetime. Level low commitment means employees feel apathetic towards the organization and its purpose.

Assessment of a lecturer on these 9 aspects of organizational climate will vary from one to another. This appreciation or perception is very subjective and personal, each lecturer brings understanding and personal value of each. Favorable or unfavorable perception a lecturer to the environment of university, depends on the suitability of environmental conditions and their perception. If it felt not appropriate, then it never he experienced / feel. Even if the condition is felt, it is more likely to lead to less favorable conditions. Vice versa, if perceived a suitable working conditions, then the conditions that are felt during work and support the work. 
Viewed from the variable happiness at work, which consists of 3 aspects, namely (1) work it self, is the source of the emergence of happy feeling of work. This can be applied to specific types of work that are closely related to profession. In the sense that, in addition to work, employees are currently performing a role as a particular profession. (2) Job context, can be a source of happiness because it is closely related to work it self, such as income received from work, relationships, facilities provided, appreciation when successful and other context related to the job. and the last is (3) Organizational context, this context can also be a source of happiness because the agency where work also gives effect to the happiness happening, for example when we work in institutions that make employees proud, will be different from working in an ordinary institution.

Diener \& Diener (2008) describes that happiness at work can be interpreted as an enthusiastic feeling for work, eager to come to work, have good relationships with colleagues, show interdependence with others or other areas in the workplace, have a good work performance, get along with other employees, willing to cover or want to replace their peer work schedule when needed, work on some side project that aims to improve the workplace, products, and services to the job.

Based on the results of regression tests to see how far the role of organizational climate to the happiness of employees in the workplace, the results obtained in table 1. Based on the table, it appears that organizational climate has a role high enough to the emergence of Employee Happiness in the Workplace, with contribution value of $61.1 \%$ and Coefficient level of 0.782 . This means that the high level of employee happiness is strongly influenced by organizational climate. When the work situation is perceived as less conducive or unfavorable, it is reasonably predictable that the level of worker happiness in the workplace will be reduced. less happy employees are less reliable to contribute significantly to organizational achievement.

TABLE I: The Role of Organizational Climate to Happiness at Work

\begin{tabular}{lccc}
\hline \hline Aspect & $\begin{array}{l}\text { Value of } \\
\text { Contribution }\end{array}$ & $\begin{array}{l}\text { Coefficient } \\
\text { Level }\end{array}$ & Significant \\
\hline $\begin{array}{l}\text { The Role of Organizational } \\
\text { Climate to Happiness at Work }\end{array}$ & $61.1 \%$ & 0.782 & $\mathrm{p}<0.05$ \\
\hline \hline
\end{tabular}

In table 1 , as we can see that the value of this contribution can be categorized high, but the rest of it, about $38.9 \%$ influenced by other factors.

\section{Conclusion}

Organizational climate has been shown to contribute greatly to create happiness at work. This can be one of the factors to build formation of happiness in the organization, in this study is specialized in educational organizations ie University. If the organization wants a happy employee, so that it can provide optimal performance results, then University needs to pay attention to the existing climate and check how the lecturer perceived or perception it.

This research is not yet perfect, and still needs to be continued. Although organizational climate contributes greatly, but further research needs to be done to get other factors that can build happiness at work.

\section{Acknowledgements}

This work would not have been possible without the the help of almighty God, Allah SWT. The parents of researchers, member of research team, collegas of researchers, departement of industry and organizational faculty of psychology, and last but not least, the university where i work, Universitas Padjadjaran.

\section{References}

[1] Chong, V. K., \& Eggleton, I. R. C. (2007). The impact of reliance on incentive-based compensation schemes, information asymmetry and organizational commitment on managerial performance. Management Accounting Research, 18, 312-342.

[2] Diener, E. (2000). Subjective well-being. American Psychologist, 55, pp. 34-43. 
[3] Diener, E. and Diener, C. (1996). Most people are happy. Psychological Science, 96, pp. 181-185.

[4] Diener, .E., Lyubomirsky, .S. \& King .L. 2005. The Benefit of Frequent Positive Affect: Does Happiness Lead Succes?. Psychological Bulletin. Vol. 131, no. 6, hal $803-855$.

[5] Estrada, C, Isen, A. M., \& Young, M. J. (1994). Positive Affect Influences Creative Problem Solving and Reported Source of Practice Satisfaction in Physicians. Motivation and Emotion, Vol. 18, Hal. 285-299.

[6] Fisher, C. D. (2010). Happiness at work. International Journal of Management Reviews, 12, 384-412.

[7] Hales, J., \& Williamson, M. G. (2010). Implicit employment contracts: The limits of management reputation for promoting firm productivity. Journal of Accounting Research, 48(1), 51-80.

[8] Hosie, P., Willemyns, M., \& Sevastos, P. (2012). The impact of happiness on managers' contextual and task performance. Asia Pacific Journal of Human Resources, 50, 268-287.

[9] Kelloway, E. K., \& Day, L. A. (2005). Building healthy workplaces: What we know so far. Canadian Journal of Behavioural Science, 37(4), 223-249.

[10] Kiriago, Aloy Nyagechi; Bwisa, Henry M. 2013. "Working Environment Factors that Affect Quality of Work Life among Attendants in Petrol Station in Kitale Town in Kenya". International Journal of Academia Research in Business and Social Sciences. Vol. 3. No. 5.

[11] Seligman, M.E.P. and Csikszentmihalyi, M. (2000). Positive psychology: an introduction. American Psychologist, 55pp. 5-14.

[12] Quick, J. C., \& Quick, J. D. (2004). Health, happy, productive work: A leadership challenge. Organizational Dynamics, 33(4), 329-337.

[13] Rego, A., \& Cunha, M. P. (2008). Authentizotic climates and employee happiness: Pathways to individual performance? Journal of Business Research, 61, 739-752.

[14] Samnani, A., \& Singh, P. (2014). Performance-enhancing compensation practices and employee productivity: The role of workplace bullying. Human Resource Management Review, 24, 5-16.

[15] Simmons, B. L. (2014). Organizational characteristics of happy organizations. In P. Y. Chen, \& C. L. Cooper (Eds.), Work and wellbeing (pp. 1-18). Hoboken: John Wiley \& Sons, Inc.

[16] Sloan, M. M. (2005). There is no happiness at work! Emotion management, inauthenticity, and psychological distress in the workplace. Unpublished PhD's thesis. Vanderbilt University, United States.

[17] Thompson, G. M., \& Goodale, J. C. (2006). Variable employee productivity in workplace scheduling. European Journal of Operational Research, 170, 376-390. 